\title{
Influence of Working Capital Management and Liquidity on Financial Soundness of Firms Listed At Karachi Stock Exchange
}

\author{
Ammar Ali Gull ${ }^{1}$, Masood Arshad ${ }^{2}$ \\ ${ }^{1 \& 2}$ (School of Banking and Finance, GC University Faisalabad, Pakistan)
}

\begin{abstract}
This particular study tries to assess the nature of relationship of Working Capital Management (WCM) and liquidity with firm's performance. Most important issue for the firms is to decide the best suitable level of working capital which can satisfy both motives $f$ liquidity and profitability. Financial performance is measured by return on capital employed while determinants of working capital and liquidity includes inventory turnover, accounts receivable turnover, current and quick ratio. A sample of 19 cement companies listed on Karachi Stock Exchange for a period of 2005 to 2010 has been taken out off 29 firms on the basis of availability of data. Finally outcomes of bivariate analysis suggested that efficient management of working capital and liquidity leads to financial success.

Keywords - Accounts Receivable Turnover, Current Ratio, Inventory Turnover, Karachi stock exchange (KSE).
\end{abstract}

\section{INTRODUCTION}

Financing needs of the corporations are of two types. One is short term and other is long term. Many researchers have done remarkable work on long-term financing decisions of the firm. However from the perspective of short term financing needs financial managers are attempting to define the rational level of working capital, which ultimately enhance the shareholders equity. Working capital includes currents assets and currents liabilities of firm. Currents assets include the most liquid assets such as cash, account receivable, and inventory of the firm. Whereas account payable and short term debts are the elements of current liabilities. Another important factor to measure the firm's profitability is the cash conversion cycle (CCC). Basic aim of cash conversion cycle is to determine the extent of time that is required by the company to transform its resources into operating cash flows. It starts from the payment to supplier for purchase of raw material and ends up with the receipt of revenue from the customer through sales. In more precise manner cash to cash cycle looks at the time required to sell goods to customers, time required to collect receivable from the debtors and time span to mature its obligations regarding payables without affecting its credit ratings. Cash conversion cycle represents no. of days in which inventory is outstanding, days sales outstanding and the days in which payables are outstanding. Account payable is another element of cash conversion cycle. Account payable turnover days refer to the time period after which payment is due from the supplier. Delaying payment to its creditors enhance the firm ability to get better quality of raw material and elastic source of financing. However, too much delay in payment to the creditors will adversely affect the profitability and lowers the credit ratings for the firm in the business environment. The customary view regarding the association between the working capital and cash conversion cycle with the profitability is that shorter the cash conversion cycle better the profitability position of the firm and vice versa. Working capital management is a famous topic in scholars of corporate finance. Every business entity wants to enhance its profitability and liquidity with the passage of time. Every business organization has to deal with short term assets and liabilities in a best possible manner to maintain a good liquidity position. Horne and Wachowicz (2000) proposed that firms with best management of current assets and liabilities can achieve higher rate of return on their investment and strong liquidity position. Eljelly (2004) narrates the idea that when a firm is able to manage its short term resources and obligations efficiently, it will eliminate the inability of meeting short term obligations. Top level management has to deal with most of conceptual skills and decisions. Manager in many organizations spend significant time in taking assessment for making best combinations of current assets and current liabilities in order to maintain their strong liquidity and profitability position. Liquidity doesn't mean to pay back its debts at the time of liquidation but it means to maintain a good repute in the eyes of creditors in terms of short term day to day payments. So with this indication, it becomes an integral part of management decision making to select the best combination of current assets and current liabilities as clarified by joshi (1994).

\section{1, Research Objectives}

This study will concentrate on the following goals.

To asses is there any significance association between working capital management and profitability of firms.

To find out the degree up to which these elements are crucial for firm's financial outcomes.

To assess the level of influence up to which profitability is affected by elements of working capital. 


\section{Literature ReVIEW}

In the field of managerial finance managing working capital elements is a key issue for every business organization. Joshi (1994) stated that only due to effective management of working capital a firm can maximize its return on investment which affects the profitability. No doubt definite goal of the firm is to maximize the profit but keeping the optimal combination of current assets and liabilities is an integrated part for the overall corporate strategy too. Market competition and business productivity is highly affected by working capital management. Various other scholars have described the same idea that working capital management is the key objective of every finance manager. Working capital means money that is used by the firm for the purpose of its daily needs. It is that portion of total assets which is used in meeting daily expenses of business. Outcomes of prior studies reveal the fact that working capital management is the key element in financial decision making of all business concerns, because finally it concludes the operating profitability both in terms of efficiency and effectiveness. For survival of every business organization working capital management is an integral element of overall business strategy. Smith (1980) reveals that working capital management affects the firm profitability. Deloof (2003) narrates that market value of the firm can only be increased by the management of working capital. In recent times a lot of studies are conducted to explore the association between profitability and working capital management. Researchers has emphasized on inventory turnover and accounts receivable for this tenacity. Prior scholars Afza and Nazir (2007) have concluded that there is a strong negative association between account receivable turnover, inventory turnover, and cash conversion cycle (CCC) with reference to the profitability of the firm. Firm with greater liquidity ratio and better working capital management will achieve remarkable profitability on its investment. Ningning, Xinging and Juan (2006) revealed that account receivable turnover, inventory turnover and cash conversion cycle (CCC) have adverse relationship with profitability, while account payable cycle has positive connection. Shin and soenen (1998) said that firm's liquidity position is also determined by working capital. Liquidity position measures the ability of firms to meet their short term obligations when they become due. If a firm does not meet its short term obligations on time it is said to be insolvent (Dunn and Cheatham, 1993). However, too much liquidity position will also lower the profitability of the firm. Value of the firm can be maximized if there is appropriate trade-off between liquidity and profitability. Deloof (2003) explained that finding an ideal level of working capital and liquidity position is very problematic task for the firms. Nunn (1981) and Kim and Srinivasan (1988) and Lazaridis and Tryfonidis (2006) explained that working capital management of the firm is determined by production processes and technological features. They also explored the idea that level of working capital selected by the firm depends on the firm-specific factors such as capital intensity, profitability, and size of the firm etc. Ultimate objective of the firms is to maximize the shareholders wealth but maintaining the liquidity position is an important objective too. Increasing profitability at the cost of liquidity carries serious problems for the firm. For this consideration, working capital management is very important decision. Most of the firms has invested significant amount of cash in working capital (Deloof, 2003). So it is clear that working capital management have a substantial impact on profitability of firms. He found that there is a negative relationship between account receivable turnover in days, inventories in the stock, account payable in days and gross operating income (GOI), with respect to Belgian firms. Previous studies concluded that companies can enhance their productivity in terms of profitability by shortening the cash cycle (CC) (Deloof, 2003; Lazaridis and Tryfonidis, 2006). But on the other hand, disagreements regarding the shorter cash conversion cycle also exist. If a company has a long inventory turnover it ultimately lowers down the chance of uncertainty on the subject of delivery stoppage. Shah (2009) narrated that through substantial credit policy a firm can enhance its relations with the customers and get higher sales return. Researchers have observed a strong negative relationship between the cash cycle and profitability. Managing current assets and current liabilities represents the operational efficiency (Lazaridis and Tryfonidis, 2006). Besides the above described theoretical framework, the additional three conceptual philosophies are also imperative. These theories include resource based view of the firm, agency theory, and transactions cost theory.

\section{Resource Based View Theory}

In resource based view theory the fundamental assumption is that when the proprietor and managers accumulate the distinctive resources, it in long run provides a competitive edge to the firm. This notation was explained by (Wernerfelt, 1984). Firm resources include both physical and non-physical. Tangible resources refer to those assets which have actual existence in the business environment. Whereas intangible refers to the good will of the business, knowledge and procedures etc.

\section{Agency Theory}

The major assumption in the agency theory is that managers are the agents of the owners. If they don't perform their duties in good and organized manner in order to enhance and protect the wealth of owners, an agency problem exists. It's their prime responsibility to enhance the shareholders' value and minimize the problems. 
Formalized management system can reduces the risk of agency issue. Normally in the small firms formalized management system perform well because owners are hardly willing to take consent of employees (Nayak and Greenfield, 1994).

\section{Transaction Theory}

Management of the business has to acquire information for securing the benefit of the shareholders. Transaction cost means the expenses which are incurred to acquire the required information. Mian and smith (1992) suggested that efficient management system is one in which the desired results are always more than the actual one. Firm will invest its resources into those projects where they expect to attain the maximum margin. Many small firms have minimum margins on their investment with respect to the working capital. These firms invest a very low amount in working capital. Some firms invest their resources in a particular element of working capital.

From the above discussion it is understandable that firm can increase its value through achieving the optimum level of working capital. Effective management of the firm's resources will lead to the corporate profitability both in terms of productivity and efficiency. Hence from the above debate working capital management of the business can be determined by efficient cash conversion cycle, and liquidity position. Most of the prior studies were constructed on the western data sets. Only a few studies are conducted in the Pakistan and specifically with reference to the cement manufacturing firms. Thus present study will tell us that outcomes of this research are in accordance with prior studies or not.

\section{ReSEARCH Methodology}

Methodology of this study is based on univariate and bivariate analysis. Univariate analysis refers to the analysis of each and every variable on the basis of its central tendency i.e. mean, median, mode and measures of dispersion like range, and standard deviation. Bivariate analysis discusses the correlation and regression analysis between two variables. If two variables are correlated, than this can be measured through the various quantitative statistical techniques like Pearson correlation analysis. In current study researchers will investigate the univariate and bivariate analysis of various factors affecting the profitability. At final stage scholars will examine the causal relationship between the dependent and independent variables with respect to working capital and profitability of the firms. This causal association will be investigate through regression analysis.

\section{1, Sample}

For the purpose of this study a sample of 19 firms listed in cement sector at Karachi Stock Exchange for the period of 2005 to 2010 was selected out off 29 companies on the basis of availability of data.

\section{2, Data Sources}

- Audited annual report and accounts

- Other statutory statements

- $\quad$ Prospectuses

- Economics publications

- $\quad$ State Bank Publications

- $\quad$ Press Cuttings

- $\quad$ World Wide Web

- $\quad$ Books and other Publications.

\section{3, Variables of Study}

Different dependent and independent variables have been selected on the basis of their significance in past studies. The important for these endogenous and exogenous variables with their null and alternative hypothesis are as follows:

\subsection{1, Return on capital employed (ROCE)}

ROCE is a measure of how company is performing its operating activities from its employed capital. The capital employed consists of all long term funds that are used by company in generating revenue. It is calculated by subtracting the current liabilities from total assets. Previous studies have revealed the fact that return on capital employed must be greater than borrowing cost of the firm if it want to survive over a longer period of time. The idea behind is that higher borrowing cost will reduce the earning capacity and lead to ultimate hardship. Return on capital employed can be calculated with the help of following formula

$$
\text { ROCE }=\frac{\text { Earnings Before Interest and Taxes }}{\text { Total Capital Emplyed }}
$$


Where the total capital employed means the total amount of equity and non-current liabilities or total asset minus current liabilities.

\subsection{2, Current Ratio (CR)}

Financing needs of the corporation are of two types. One is the short term and the other is long-term. Meeting its short term obligations in time when it will become due is the key component which designates the firm's solvency (ability to pay back debts). Liquidity ratios are the main acting element, which define the margin of safety for the firm. High liquidity ratios i.e. (CR) mean higher the ability to meet current obligations and vice versa. On the other hand it is also a controversial point that if a firm maintains excessive liquidity. So it will reduce the profitability of the firm because most liquid assets are seized in the form of extra funds. Current ratio is a measure of firm's liquidity and it can be calculated with the help of following formula.

$$
\text { Current Ratio }=\frac{\text { Current Assets }}{\text { Current Liabilities }}
$$

\subsection{3, Quick Ratio or Acid Test Ratio (QR)}

In current assets of the business inventory is considered as least liquid asset. Most important reason for inventory to be considered least liquid is that many types of inventories can't be sold in time because it contains incomplete items. The second idea behind is that most of the inventory is to be sold out on credit basis and it become receivables before it is converted into cash. Firm can measure its better liquidity position with acid test ratio when its inventory is not easily converted into cash. So for this purpose acid test ratio defines the quick or liquid assets in the business.

$$
\text { Quick Ratio }=\frac{\text { Current Assets }- \text { Inventory in stock }}{\text { Current Liabilities }}
$$

\subsection{4, Inventory Turnover Ratio (ITR)}

Inventory turnover is another element of working capital. Inventory turnover determine the days a firm needs to convert its inventory into sales. Normally inventory turnover is calculated by dividing the cost of goods sold by average inventory. Average inventory in the business consists of total amount in opening and ending balance divided by 2 . Inventory turnover determines the management's efficiency in determining the efficient level of stock in the business. Firm has to face the issue of overstock which may lead to increase in inventory cost just because of lower inventory turnover ratio.

$$
\text { Inventory Turnover Ratio }=\frac{\text { Cost of Goods Sold }}{\text { Average Inventory }}
$$

\subsection{5, Accounts Receivable Turnover Ratio (ARTR)}

Accounts receivable turnover ratios measure the days in which firm converts its receivable into cash. If receivable turnover ratio is high then firm is managing its working capital in an efficient way and vice versa. In calculating the account receivable turnover ratio firms use net credit sale. If a firm uses the cash sale it will lead to confusion. The whole calculation can be done with the help of following formula.

$$
\text { Accounts Receivable Turnover Ratio }=\frac{\text { Net Credit Sales }}{\text { Average Accounts Receivable }}
$$

Where average account receivable can be calculated by adding the opening and ending balances of the receivable and dividing it by 2 .

\section{4, Empirical Models}

Regression model is used to explore the association among profitability working capital management of firms. Our base model is written below

Firm's Profitability $=\mathrm{f}($ Working Capital Management $)$. ...

Where profitability is measured by return on capital employed and determinants of working capital management includes Current ratio, quick ratio, inventory turnover ratio and accounts receivable ratio.

Return on Capital Employed = f (Liquidity Ratio, Current Ratio, Inventory Turnover Ratio and Accounts Receivable Ratio)..................... (2)

$\mathrm{Y}_{\mathrm{it}}=\beta_{0}+\beta \mathrm{X}_{\mathrm{it}}+\mu_{\mathrm{it}} \quad \mathrm{i}=1,2,3, \ldots, 19$ and $\mathrm{t}=1,2, \ldots, 6$

Where:

$Y_{\text {it }} \quad$ is called dependent variable.

$\beta_{0} \quad$ represents the intercept.

$\mathrm{X}_{\mathrm{it}} \quad$ is independent variable. 
$\mu_{\mathrm{it}} \quad$ are the error terms.

$\mathrm{i} \quad$ is number of companies and

$\mathrm{t}$ is number of years.

So, we can write our main equation (1) as:

$$
\mathrm{ROCE}=\beta_{0}+\beta_{1} \mathrm{CR}_{\mathrm{it}}+\beta_{2} \mathrm{QR}_{\mathrm{it}}+\beta_{3} \mathrm{ITR}_{\mathrm{it}}+\beta_{4} \mathrm{ARTR}_{\mathrm{it}}+\mu_{\mathrm{it}} \ldots \ldots \ldots
$$

\section{RESUlTS AND DisCuSSIONS}

As mentioned in methodology this study is based on univariate and multivariate analysis. Table- 01 exhibits the results of univariate or descriptive analysis for a sample of 19 cement manufacturing companies listed at KSE from 2005 to 2010. This table represents the six years summary of mean, standard deviation, maximum, minimum, skewness and kurtosis for dependent (ROCE) and independent variables (CR, QR, ITR \& ARTR) of study.

Table- $02 \& 03$ will elaborate the outcomes of multivariate analysis. Before selecting explanatory variables it is useful to determine whether there is high degree of correlation between variables or not. This problem is so called multicolinearity. For this purpose Pearson correlation analysis is used. The Pearson correlation matrix for the defined set of variables is presented in the Table- 02 . These values represent the level of correlation among independent variables. Only accounts receivable turnover ratio is negatively correlated to all other measures namely CR, QR \& ITR. All variables except ARTR are positively associated with each other. From findings of correlation analysis it is clear that multicolinearity problem does not exist. This issue exists only when the value of any variable is greater than 0.80 as stated by Kennedy (2008).

Regression model is used to explore the impact of liquidity and working capital management on profitability of cement industry. Table- 03 demonstrates the findings of regression analysis. R Square for ROE is 0.54833 , according to it $54 \%$ of change in return on capital employed is due to independent variables and $46 \%$ deviation in dependent variable is not due to determinants of WCM and liquidity used in model. This model has an F-statistics 15.7482 and Its Constant coefficient is a positive value 0.4767 . CR is having a strong favorable association with return on capital employed, if current ratio will increase then ROCE will also increase and vice versa. There is a positive but insignificant relationship among quick ratio and profitability of cement sector. Both ITR \& ARTR having an inverse connection with return on capital employed. Simply it means with decrease in inventory turnover ratio in days $\&$ accounts receivable turnover ratio in days ROCE will rise due to efficient use of economic resources and it will decline with increase in these ratios.

\section{CONCLUSIONS}

Working capital management and liquidity determinants of firm has a significant impact on profitability. Higher the current ratio higher will be the financial performance of firm. Quick ratio has an insignificant effect on ROCE. ITR is found to have a strong negative connection with profitability it means with rise in inventory turnover in days return on capital employed will fall and vice versa. Profitability is adversely affected by ARTR, further it mean ROCE will increase with decrease in accounts receivable turnover in days and fall with rise of ARTR. Finally it is suggested firms have to utilize their short term resources with utmost care to maintain an optimum level working capital in order to achieve the goal of financial well being.

\section{1, Future Research}

This study has focused on management of working capital and its consequences on profitability of Pakistan's cement sector. Validity of current research can be enhanced by adding more industries like sugar, petroleum, telecommunication, textile, infrastructure and many more to assess the influence of WCM has on profitability. Addition of some other variables i.e. capital structure, Assets turnover and Solvency ratios can be done along with measures of WCM to make a better model in order to explain this relationship in a more accurate way.

\section{REFERENCES}

[1] J. C. V. Horne, and J. M. Wachowicz, Fundamentals of Financial Management (11 ${ }^{\text {th }}$ Ed. Prentice Hall Inc, 2000).

[2] Eljelly, Liquidity-Profitability Tradeoff: An empirical Investigation in an Emerging Market, International Journal of Commerce \& Management, 14(2), 2004, 48-61.

[3] P. V. Joshi, Working Capital Management under Inflation 1st Ed (Anmol Publishers, 1995).

[4] K. Smith, Profitability versus Liquidity Tradeoffs in Working Capital Management, in Readings on the Management of Working Capital (New York: St. Paul, West Publishing Company, 1980).

[5] M. Deloof, Does Working Capital Management Affect Profitability of Belgian Firms?, Journal of Business, Finance and Accounting, 30, 2003, 573-587.

[6] T. Afza, and M. S. Nazir, Working Capital Management Policies of Firms: Empirical Evidence from Pakistan, Proc. 9th conf. on South Asian Management Forum (SAMF), North South University, Dhaka, Bangladesh, 2007,

[7] K. Ningning, Z. Xining, and L. Juan, The influence of working capital management efficiency on the company profitability, Nankai Business Review, 12, 2006, 121-126.

[8] H. H. Shin, and L. Soenen, Efficiency of Working Capital and Corporate Profitability, Journal of Finance Economic, 8, $1998,37-45$. 
[9] P. Dunn, and L. Cheatham, Fundamentals of small business financial management for start-up, survival, growth, and changing economic circumstances, Managerial Finance, 19, 1993, 1-13.

[10] K. Nunn, The strategical determinants of working capital: a product line perspective". Journal of Financial Research, 4, 1981, 207-219.

[11] Y. Kim, and V. Srinivasan, Advances in Working Capital Management (JAI Press: Greenwich Connecticut, 1998).

[12] I. Lazaridis, and D. Tryfonidis, Relationship between working capital management and profitability of listed companies in the Athens stock exchange, Journal of Financial Management and Analysis, 19, 2006, 26-35.

[13] N.H. Shah, Optimization of pricing and ordering under the two-stage credit policy for deteriorating items when the end demand is price and credit period sensitive, International Journal of Business Performance and Supply Chain Modeling, 1(2/3), 2009, 229-239.

[14] B. Wernerfelt, A resource based view of the firm, Strategic Management Journal, 5, 1984, 171-180.

[15] A. Nayak, and S. Greenfield, The use of management accounting information for managing micro businesses (In A. Hughes, Storey, D.J. Edition, Finance and the Small Firm, Routledge London, 1998).

[16] S. L. Mian, and C. W. Smith, Accounts receivable management policy: theory and evidence, Journal of Finance, 47, 1992, 169-200.

\section{List of Tables}

\section{Table 01}

Descriptive statistics

\begin{tabular}{llllllll}
\hline Variables & $\mathbf{N}$ & Mean & S.D & Minimum & Maximum & Skewness & Kurtosis \\
\hline ROCE & 114 & 3.873158 & 24.63504 & -65.16 & 107.18 & 1.012851 & 6.907325 \\
CR & 114 & 0.872456 & 0.602684 & 0.14 & 3.02 & 1.216401 & 4.231778 \\
QR & 114 & 0.332281 & 0.495145 & 0.009 & 2.78 & 2.230813 & 8.334527 \\
ITR & 114 & 30.78123 & 55.51337 & 0.007 & 564.12 & 7.981946 & 76.26798 \\
ARTR & 114 & 26.47872 & 76.15623 & 7.44 & 384.2294 & 3.771920 & 16.32955 \\
\hline
\end{tabular}

\section{Correlation t Matrix}

\section{Table 02}

\begin{tabular}{lllll}
\hline & QR & CR & ITR & ARTR \\
\hline QR & 1.000000 & -- & -- & -- \\
CR & 0.799174 & 1.000000 & -- & -- \\
ITR & 0.065376 & 0.015985 & 1.000000 & -- \\
ARTR & -0.118882 & -0.210248 & -0.145559 & 1.000000 \\
\hline
\end{tabular}

\section{Regression Analysis}

Table 03

\begin{tabular}{|c|c|c|}
\hline \multicolumn{3}{|c|}{ Return on Capital Employed } \\
\hline Variables & Coefficient & T-statistics \\
\hline \multicolumn{3}{|c|}{$\Gamma$-statistics is significant at the level of $5 \%$. } \\
\hline C & 0.4767 & 1.8557 \\
\hline $\mathbf{C R}$ & 0.2935 & $2.8314^{*}$ \\
\hline QR & 0.1173 & 1.2682 \\
\hline ITR & -0.1286 & $-4.7351 *$ \\
\hline ARTR & -0.1759 & $-3.7548^{*}$ \\
\hline R-squared & \multicolumn{2}{|c|}{0.5483} \\
\hline F-statistic & \multicolumn{2}{|c|}{15.7482} \\
\hline Observations & \multicolumn{2}{|c|}{114} \\
\hline
\end{tabular}

